\title{
Carbadox, formic acid and potato fibre as feed additives for growing pigs
}

\author{
Hilkka Siljander-Rasi, T. Alaviuhkola and Kaija Suomi
}

\author{
Agricultural Research Centre of Finland, Pig Research \\ Tervamäentie 179, 05840 Hyvinkää, Finland
}

\begin{abstract}
A growth trial was conducted on 160 pigs to evaluate the effect of different types of feed additives on performance. The barley-oats-soyabean meal-based diets were supplemented with either carbadox ( 0 or $50 \mathrm{mg} / \mathrm{kg}$ ) or potato fibre (Povex, 0 or $20 \mathrm{~g} / \mathrm{kg}$ ) in the growing period, or with formic acid $(0$ or $8 \mathrm{~g} / \mathrm{kg}, 85 \% \mathrm{v} / \mathrm{w})$ throughout the trial. No interactions between the feed additives were observed. Both carbadox and formic acid improved, but potato fibre tended to impair the performance of growing pigs (22-51 kg liveweight, LW). Formic acid did not affect the performance of the finishing pigs (5]-102 kg LW). In the finishing period the pigs fed grower diets without carbadox or formic acid compensated fully for their reduced performance. The performance of pigs fed grower diets with potato fibre remained poorer than that of pigs fed without addition of fibre.
\end{abstract}

KEY WORDS: pig, performance, antimicrobial feed additives, fibre, organic acids

\section{INTRODUCTION}

The routine use of antimicrobial feed additives in order to prevent diarrhoea and growth delay in young pigs is being increasingly questioned due to the development of resistant bacteria in animals (Mathew et al., 1998), and the transfer of resistance to humans (Nijsten et al., 1994). Therefore, safer alternatives to feed antimicrobials are needed. The growth-promoting effect of organic acids, such as formic acid, have been demonstrated in growing-finishing pigs (Baustad, 1993; Kirchgessner et al., 1997; Øvcrland and Lys $\varnothing, 1997)$, but few studies have separated their effects between the growing and finishing periods.

It has also been suggested that dietary inclusion of pectin-rich non-starch polysaccharides, which have a high water-holding capacity, could decrease the risk of diarrhoca by preventing the attachment and development of pathogens in the small 
intestine (Decuypere and Spriet, 1995; Göransson et al., 1995). However, little information exists on their efficiency in growing pigs.

The aim of our study was to evaluate the effects on pig performance of carbadox and potato fibre supplementation of grower diets, and formic acid supplementation of grower and finisher diets.

\section{MATERIAL AND METHODS}

A total of 160 pigs with an average initial weight of $22 \mathrm{~kg}$ were used in the growth trial. Two gilts and two barrows were randomly selected for each pen, and the pens were randomly allotted to eight dietary treatments, five pens to each treatment. Pelleted basal grower and finisher diets were formulated to contain $8.6 \mathrm{~g}$ and $7.7 \mathrm{~g} / \mathrm{kg}$ ileal digestible lysine and a similar net energy (NE) content (1.03 feed units/kg; $1 \mathrm{FU}=9.3 \mathrm{MJ} \mathrm{NE}$ ). The main dietary ingredients were barley, oats and soyabean meal $(609,130$ and $175 \mathrm{~g} / \mathrm{kg}$ for grower and 660,120 and $135 \mathrm{~g} / \mathrm{kg}$ for finisher diets, respectively). Both feeds contained $20 \mathrm{~g} / \mathrm{kg}$ wheat syrup and $30 \mathrm{~g} / \mathrm{kg}$ animal fat and were fortified with free lysine, methionine and threonine. Vitamins and minerals were added to fulfil the requirements of pigs.

The eight dietary treatments were arranged $2 \times 2 \times 2$ factorially. The factors were the supplementation of the grower diet with either carbadox $(0$ or $50 \mathrm{mg} / \mathrm{kg}$, days 1-33) or potato fibre (Povex, Lyckeby Stärkelsen, Sweden, 0 or $20 \mathrm{~g} / \mathrm{kg}$, days $1-26)$, or the supplementation of the grower and finisher diet with formic acid $(0$ or $8 \mathrm{~g} / \mathrm{kg}, 85 \% \mathrm{v} / \mathrm{w}$ ). Potato fibre was mixed into the diets before feeding. A restricted age-based feeding scale (1.2-3.2 kg feed/d) was used. The feeds were given twice daily in the form of wet mash.

The carbadox in the feeds was determined by high-performance liquid chromatography and formic acid with a commercial kit (Boehringer-Mannheim, 979 732). Potato fibre was analysed for water-holding capacity (Robertson and Eastwood, 1981, with modifications) and dietary fibre (Theander et al., 1995). The growth data were subjected to a least-squares analysis of variance with the effects of carbadox, potato fibre, formic acid and their interactions; and the interaction of carbadox, formic acid and potato fibre within the pen. The latter was used as an error term for the main effects and their interactions. Feed consumption was measured on a pen basis, and the pen effect was thus excluded from the model.

\section{RESULTS AND DISCUSSION}

The analysed carbadox content of the grower diets was, on average, $31 \mathrm{mg} / \mathrm{kg}$. The formic acid content of the grower and finisher diets averaged $7.5 \mathrm{~g}$ and $6.4 \mathrm{~g} / \mathrm{kg}$, 
TABLE 1

Effect on pig performance of supplementation of grower diets with either carbadox or potato fibre, or grower and finisher diets with formic acid

\begin{tabular}{|c|c|c|c|c|}
\hline Carbadox in grower diet & $0 \mathrm{mg} / \mathrm{kg}$ & $50 \mathrm{mg} / \mathrm{kg}$ & SEM & Signific. \\
\hline \multicolumn{5}{|l|}{ Growing period, $22-51 \mathrm{~kg}$} \\
\hline final weight, $\mathrm{kg}$ & 51.0 & 51.8 & 0.39 & \\
\hline daily weight gain, $\mathrm{g}$ & 871 & 900 & 8.60 & * \\
\hline $\begin{array}{l}\text { feed conversion ratio, } \mathrm{kg} \mathrm{DM} / \mathrm{kg} \\
\text { finishing period, } 51-102 \mathrm{~kg}\end{array}$ & 1.64 & 1.58 & 0.01 & ** \\
\hline daily weight gain, $\mathrm{g}$ & 1047 & 1022 & 9.79 & 0 \\
\hline feed conversion ratio, $\mathrm{kg} \mathrm{DM} / \mathrm{kg}$ & 2.35 & 2.42 & 0.03 & 0 \\
\hline \multicolumn{5}{|l|}{ Total fattening period, $22-102 \mathrm{~kg}$} \\
\hline daily weight gain, $\mathrm{g}$ & 972 & 974 & 6.16 & \\
\hline feed conversion ratio, $\mathrm{kg} \mathrm{DM} / \mathrm{kg}$ & 2.09 & 2.11 & 0.02 & \\
\hline days in experiment & 82.0 & 83.1 & 0.78 & \\
\hline Potato fibre in grower diet & $0 \mathrm{~g} / \mathrm{kg}$ & $20 \mathrm{~g} / \mathrm{kg}$ & SEM & Signific. \\
\hline \multicolumn{5}{|l|}{ Growing period, $22-51 \mathrm{~kg}$} \\
\hline final weight, $\mathrm{kg}$ & 52.0 & 50.8 & 0.39 & * \\
\hline daily weight gain, $g$ & 898 & 874 & 8.60 & 0 \\
\hline feed conversion ratio, $\mathrm{kg} \mathrm{DM} / \mathrm{kg}$ & 1.59 & 1.62 & 0.01 & \\
\hline \multicolumn{5}{|l|}{ Finishing period, $51-102 \mathrm{~kg}$} \\
\hline daily weight gain, g & 1047 & 1021 & 9.87 & 0 \\
\hline feed conversion ratio, $\mathrm{kg} \mathrm{DM} / \mathrm{kg}$ & 2.35 & 2.42 & 0.03 & 0 \\
\hline \multicolumn{5}{|l|}{ Total fattening period, $22-102 \mathrm{~kg}$} \\
\hline daily weight gain, $g$ & 983 & 963 & 6.16 & * \\
\hline feed conversion ratio, $\mathrm{kg} \mathrm{DM} / \mathrm{kg}$ & 2.07 & 2.13 & 0.02 & * \\
\hline days in experiment & 81.1 & 84.0 & 0.78 & * \\
\hline Formic acid in grower and finisher diet & ets $0 \mathrm{~g} / \mathrm{kg}$ & $8 \mathrm{~g} / \mathrm{kg}$ & SEM & Signific. \\
\hline \multicolumn{5}{|l|}{ Growing period, $22-51 \mathrm{~kg}$} \\
\hline final weight, $\mathrm{kg}$ & 50.7 & 52.1 & 0.40 & * \\
\hline daily weight gain, $g$ & 866 & 906 & 8.70 & $* *$ \\
\hline $\begin{array}{l}\text { feed conversion ratio, } \mathrm{kg} \mathrm{DM} / \mathrm{kg} \\
\text { finishing period, } 51-102 \mathrm{~kg}\end{array}$ & 1.64 & 1.58 & 0.01 & * \\
\hline daily weight gain, $g$ & 1040 & 1029 & 9.79 & \\
\hline feed conversion ratio, $\mathrm{kg} \mathrm{DM} / \mathrm{kg}$ & 2.37 & 2.39 & 0.03 & \\
\hline \multicolumn{5}{|l|}{ Total fattening period, $22-102 \mathrm{~kg}$} \\
\hline daily weight gain, $\mathrm{g}$ & 966 & 980 & 6.16 & \\
\hline feed conversion ratio, $\mathrm{kg} \mathrm{DM} / \mathrm{kg}$ & 2.11 & 2.09 & 0.02 & \\
\hline days in experiment & 83.1 & 82.0 & 0.78 & \\
\hline
\end{tabular}

Signific. $=$ significance for the main effect: $0, \mathrm{P}<0.10 ; \mathrm{P}<0.05 ;{ }^{*} * \mathrm{P}<0.01$

The additive interactions were not significant $(\mathrm{P}>0.10)$. Each result is a mean of 20 pens of four pigs 
respectively. Acidification lowered the feed $\mathrm{pH}$ by 1.1 units, a finding consistent with Baustad (1993). The water-holding capacity of potato fibre was $13 \mathrm{~g}$ water/g feed and it contained $683 \mathrm{~g}$ dietary fibre/ $\mathrm{kg}$ dry matter (DM) with a high proportion of galactose and uronic acids (149 and $191 \mathrm{~g} / \mathrm{kg} \mathrm{DM}$ ).

The pigs consumed their feed readily; feed refusals were only occasionally found. Their health status was good and their growth rate throughout the trial averaged $973 \mathrm{~g} / \mathrm{d}$. No significant interactions between the feed additives were found, although in earlier studies both organic acids (Edmonds et al., 1985) and fibre additives (Göransson et al., 1995) were reported to enhance the effect of antimicrobials. In the growing period, both carbadox and formic acid improved the daily weight gain and feed conversion ratio of the pigs. Potato fibre tended to retard the growth, which resulted in a lower liveweight at the end of the period (Table 1). Responses to feed additives were, however, rather small ( $\pm 3-5 \%$ ). Larger responses to carbadox have been obtained with young pigs and low performance levels (Raynaud, 1974). The carbadox content in our grower diets was also lower than the recommended $50 \mathrm{mg} / \mathrm{kg}$. The impairment of performance in pigs fed potato fibre may be due to the negative effect of pectin-rich dietary fibre on digestibility of cnergy and protein (Chabcauti et al., 1991).

In the finishing period formic acid had no effect on the performance of pigs. This is in agreement with Kirchgessner et al. (1997) who supplemented pig diets with potassium diformate. The pigs fed grower diets without carbadox or formic acid compensated fully for their reduced growth, and their performance between 22 and $102 \mathrm{~kg}$ was similar to that of pigs fed with these additives. In earlier studies the effect of formic acid or its salts on performance in the total fattening period had been positive, although not always significant (Baustad, 1993; Kirchgessner et al., 1997; Øverland and Lys $\varnothing, 1997)$. No growth compensation was found in pigs fed grower diets with potato fibre. Their performance in the finishing period and throughout the trial was poorer than that of the pigs fed without fibre addition. The dietary treatments did not affect the carcass quality of the pigs.

It is concluded that carbadox and formic acid have a similar positive effect on performance in growing pigs, but the use of fibrous, water-holding feed additives may reduce the performance. Formic acid treatment of finishing pigs diets does not seem necessary.

\section{ACKNOWLEDGEMENTS}

The financial support of Rehuraisio Ltd. (Raisio, Finland) is gratefully acknowledged. 


\section{REFERENCES}

Baustad B., 1993. Effects of formic acid on performance of growing pigs. Norweg. J. Agric. Sci. 7. 61-69

Chabeauti E., Noblet J., Carré B., 1991. Digestion of plant cell walls from four different sources in growing pigs. Anim. Feed Sci. Technol. 32, 207-213

Decuypere J.A., Spriet S., 1995. Influence of the water holding capacity of the diet on the incidence of diarrhoea and the colonisation of the small intestine in stressed pigs. Proceedings of $46^{\text {th }}$ Annual Meeting of the EAAP, Prague, Czech Republic, p. 4

Edmonds M.S., Izquierdo O.A., Baker D.H., 1985. Feed additives with newly weaned pigs: efficacy of supplemental copper, antiobiotics and organic acids. J. Anim. Sci. 60, 462-469

Göransson L., Lange S., Lönnroth I., 1995. Post weaning diarrhoea: focus on diet. Pig News Inf. 16, $89 \mathrm{~N}-91 \mathrm{~N}$

Kirchgessner M., Paulicks B., Roth F.X., 1997. Effects of supplementations of difomate complexes (Formi ${ }^{\mathrm{TM}} \mathrm{LHS}$ ) on growth and carcass performance of piglets and fattening pigs in response to application time. Agribiol. Res. 50, 1-10

Mathew A.G., Upchurch W.G., Chattin S.E., 1998. Incidence of antibiotic resistance in fecal Escherichia coli isolated from commercial swine farms. J. Anim. Sci. 76, 429-434

Nijsten R., London N., van den Bogaard A., Stobberingh E., 1994. Resistance in faecal Escherichia coli isolated from pig farmers and abattoir workers. Epidemiol. Infect. 113, 45-52

Raynaud J.P., 1974. Evaluation on 5500 young pigs of carbadox used at $50 \mathrm{ppm}$. Economic interpretation in reference with performances of control animals or supplements used at nutritional $(\leq 150 \mathrm{ppm})$ or therapeutic $(\geq 200 \mathrm{ppm})$ levels. Z. Tierphysiol. Tieremähr. Futtermittelk. 32, 249-278

Robertson J.A., Eastwood M.A., 1981. A method to measure the water-holding properties of dietary fibre using suction pressure. Brit. J. Nutr. 46, 247-255

Theander O., Åman P., Westerlund E., Andersson R., Pettersson D., 1995. Total dietary fiber determincd as neutral sugar residues, uronic acid residues, and Klason lignin (The Uppsala method): collaborative study. J. AOAC Int. 78, 1030-1044

$\emptyset$ verland M., Lysø A., 1997. Addition of formic acids and/or formates in diets for growing-finishing pigs. Proceedings of 48th Annual Meeting of the EAAP, Vienna, Austria, p. 6 